Article

\title{
Thermal Stability of Ru-Al Multilayered Thin Films on Inconel 617
}

\author{
Yung-I Chen *, Zhi-Ting Zheng and Jia-Wei Jhang \\ Institute of Materials Engineering, National Taiwan Ocean University, Keelung 20224, Taiwan; \\ 10455001@mail.ntou.edu.tw (Z.-T.Z.); 10555006@mail.ntou.edu.tw (J.-W.J.) \\ * Correspondence: yichen@mail.ntou.edu.tw; Tel.: +886-2-2462-2192
}

Received: 7 June 2018; Accepted: 2 July 2018; Published: 4 July 2018

\begin{abstract}
Ru-riched and equiatomic Ru-Al multilayered thin films were fabricated on Si and Inconel 617 substrates. These thin films exhibited a multilayered structure that is caused by stacking cyclical gradient concentration through cosputtering. X-ray diffraction analysis indicated that the as-deposited $\mathrm{Ru}-\mathrm{Al}$ multilayers comprised $\mathrm{Ru}$ and $\mathrm{RuAl}$ phases. Oxidation that is caused by annealing atmospheres and elements diffused from substrates was investigated. The results indicated that the inward diffusion of $\mathrm{O}$ at $600{ }^{\circ} \mathrm{C}$ in a $1 \% \mathrm{O}_{2}-99 \%$ Ar atmosphere was restricted by the formation of an amorphous Al-oxide sublayer, and inward diffusion of $\mathrm{O}$ at $800{ }^{\circ} \mathrm{C}$ in air was limited by the formation of a crystalline $\mathrm{Al}_{2} \mathrm{O}_{3}$ scale. Additionally, the outward diffusion of elements from Inconel 617 penetrated the unoxidized parts of the $800{ }^{\circ} \mathrm{C}$-annealed $\mathrm{Ru}-\mathrm{Al}$ multilayers.
\end{abstract}

Keywords: multilayer; oxidation; RuAl; thermal stability

\section{Introduction}

Inconel 617, which is a Ni-based superalloy, is widely used in metal components that must withstand temperatures above $800{ }^{\circ} \mathrm{C}[1,2]$. Thermal barrier coatings (TBCs) are employed for high-temperature applications to provide thermal and oxidation protection to metal components $[3,4]$. $\mathrm{Y}_{2} \mathrm{O}_{3}$-stabilized $\mathrm{ZrO}_{2}$ (YSZ) has been used as a TBC for gas turbine blades and vanes [5-9]. Because $\mathrm{O}$ can penetrate YSZ, aluminide bond coats (BCs) have been used to combine YSZ and Ni-based superalloys. These $\mathrm{BCs}$ behave as diffusion barriers after forming thermally grown oxides (TGO), such as $\alpha-\mathrm{Al}_{2} \mathrm{O}_{3}$. Therefore, a typical TBC/TGO/BC/superalloy assembly is a common material structure in jet engine components. RuAl exhibits excellent oxidation resistance, thermodynamic stability, and strength at high temperatures, as well as excellent ductility at room temperature [10,11]. Moreover, RuAl and $\mathrm{Al}_{2} \mathrm{O}_{3}$ possess similar coefficients of thermal expansion [12]. Accordingly, Ru-modified aluminides have been used as BCs for thermal barrier systems [13,14]. RuAl thin films that were fabricated by sputtering have also been considered for use as working layers for glass molding dies at temperatures above $600{ }^{\circ} \mathrm{C}[15,16]$ and for metallization on surface acoustic wave devices that are annealed at $800{ }^{\circ} \mathrm{C}$ under high vacuum conditions [17-20]. Therefore, it is important to understand the thermal stability of $\mathrm{Ru}-\mathrm{Al}$ thin films at high temperatures. In a previous study [21], the oxidation behavior of $\mathrm{Ru}_{0.63} \mathrm{Al}_{0.37}$ multilayered thin films prepared on Si substrates was investigated in a low-oxygen-content atmosphere of $1 \% \mathrm{O}_{2}-99 \% \mathrm{Ar}$, and the films exhibited internal and external oxidation at $400-600$ and $700-800{ }^{\circ} \mathrm{C}$, respectively. A $1 \% \mathrm{O}_{2}-99 \%$ Ar atmosphere has also been used as an oxidation-accelerating atmosphere to evaluate the performance of protective coatings on glass molding dies [22]. In the present study, the oxidation resistance of $\mathrm{Ru}_{0.48} \mathrm{Al}_{0.52}$ multilayered thin films in $1 \% \mathrm{O}_{2}-99 \% \mathrm{Ar}$ atmosphere at $600{ }^{\circ} \mathrm{C}$ was evaluated. Subsequently, the thermal stability of the $\mathrm{Ru}_{0.63} \mathrm{Al}_{0.37}$ and $\mathrm{Ru}_{0.48} \mathrm{Al}_{0.52}$ thin films that were prepared on Inconel 617 substrates in air at $800{ }^{\circ} \mathrm{C}$ was investigated. 


\section{Materials and Methods}

$\mathrm{Ru}-\mathrm{Al}$ multilayered thin films with an interlayer were fabricated through magnetron cosputtering onto silicon and Inconel 617 substrates with dimensions of $20 \times 20 \times 0.525 \mathrm{~mm}^{3}$ and $20 \times 20 \times 3 \mathrm{~mm}^{3}$, respectively. Ti and $\mathrm{Ru}$ interlayers were deposited to improve the adhesion strength of $\mathrm{Ru}-\mathrm{Al}$ thin films on Si and Inconel 617 substrates, respectively. Pure metal targets of $\mathrm{Ru}(99.95 \%), \mathrm{Al}(99.999 \%)$, and Ti $(99.995 \%)$ with diameters of $50.8 \mathrm{~mm}$ each were adopted as source materials for sputtering (Figure 1). The sputter guns were inclined to focus plasma on the circular track of the substrate holder, which resulted in cyclical gradient concentration deposition $[21,23,24]$. The cosputtering processes for fabricating multilayered thin films were described in detail in a previous study [23]. Ru and Al were cosputtered onto the interlayers using various powers, while the substrate holder was rotated at $1 \mathrm{rpm}$ and kept at $400{ }^{\circ} \mathrm{C}$ during sputtering. After sputtering Ru-Al deposits for $35 \mathrm{~min}$, the sputter power of $\mathrm{Al}$ target was turned off for an extra substrate holder revolution to fabricate a Ru layer on the surface for protective purposes [21]. The $\mathrm{Ru}-\mathrm{Al}$ thin films that were deposited on $\mathrm{Si}$ and Inconel 617 were further annealed at $600{ }^{\circ} \mathrm{C}$ in $1 \% \mathrm{O}_{2}-99 \%$ Ar and at $800{ }^{\circ} \mathrm{C}$ in air, respectively.

Chemical composition analyses were conducted using a field emission electron probe microanalyzer (FE-EPMA, JXA-8500F, JEOL, Akishima, Japan) at a 12-kV accelerating voltage on the surface. Surface morphology and thickness measurement of the thin films were performed by using a field emission scanning electron microscope (FE-SEM, S4800, Hitachi, Tokyo, Japan) at a 15-kV accelerating voltage. A conventional X-ray diffractometer (XRD, X'Pert PRO MPD, PANalytical, Almelo, The Netherlands) with $\mathrm{Cu} \mathrm{K} \alpha$ radiation was used to identify the thin film phases using a grazing incidence technique at an incidence angle of $1^{\circ}$. The accelerating voltage and the current of XRD in this study were applied for $45 \mathrm{kV}$ and $40 \mathrm{~mA}$, respectively. The nanostructure of the thin films and scales was further examined using transmission electron microscopy (TEM, JEM-2010F, JEOL, Tokyo, Japan) at a 200-kV accelerating voltage. TEM samples were prepared by applying a focused ion beam system (FEI Nova 200, Hillsboro, OR, USA) at an accelerating voltage of $30 \mathrm{kV}$ with a gallium ion source. A Pt layer was deposited to protect the free surface during sample preparation. An energy dispersive spectrometry (EDS, Inca x-sight, Oxford Instruments, Tokyo, Japan), equipped with the TEM was used to determine local chemical compositions qualitatively. The residual stress of the films prepared on Si substrates, as measured by the curvature method was calculated using Stoney's equation [25].

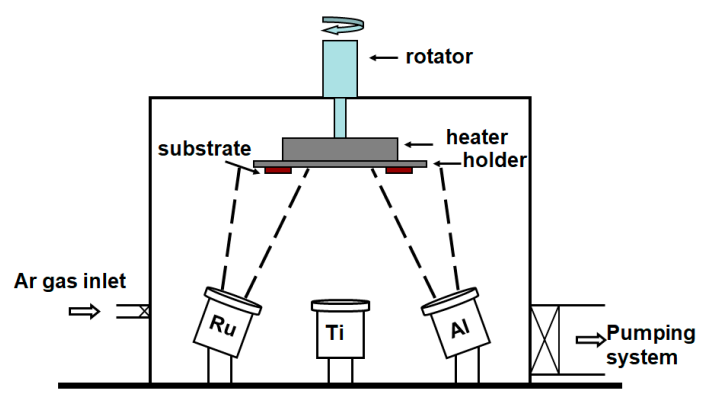

(a)

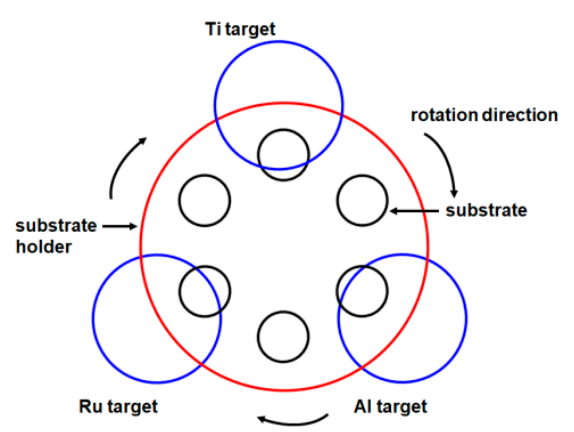

(b)

Figure 1. (a) Schematic of the cosputtering equipment and (b) substrate holder and sample positions related to sputter targets. 


\section{Results and Discussion}

\subsection{As-Deposited Ru-Al Thin Films}

Table 1 lists the chemical compositions of the as-deposited $\mathrm{Ru}-\mathrm{Al}$ thin films that were prepared on Si substrates using various sputter powers and a substrate holder rotation speed of $1 \mathrm{rpm}$. The thin films are denoted in the table as $\mathrm{Ru}_{0.89} \mathrm{Al}_{0.11}, \mathrm{Ru}_{0.63} \mathrm{Al}_{0.37}$, and $\mathrm{Ru}_{0.48} \mathrm{Al}_{0.52}$. Figure 2 presents the XRD patterns of the as-deposited $\mathrm{Ru}-\mathrm{Al}$ thin films. The $\mathrm{Ru}_{0.89} \mathrm{Al}_{0.11}$ thin films exhibited a hexagonal $\mathrm{Ru}$ [ICDD 00-006-0663] phase, whereas the $\mathrm{Ru}_{0.63} \mathrm{Al}_{0.37}$ and $\mathrm{Ru}_{0.48} \mathrm{Al}_{0.52}$ thin films exhibited a mixture of cubic RuAl [ICDD 00-029-1404] and Ru phases. The peaks at the two-theta angle of approximately $52^{\circ}$ were caused by the Si substrate [26]. The reflections of the Ti interlayers were not observed because they were of low intensity. Figure 3 depicts the XRD pattern of the $\mathrm{Ru}_{0.48} \mathrm{Al}_{0.52} / \mathrm{Ti} / \mathrm{Si}$ samples that were captured using a Bragg-Brentano scan. The scan indicated RuAl and Ru phases accompanied by a Ti phase. Figure 4 presents a cross-sectional SEM image of the as-deposited $\operatorname{Ru}_{0.48} \mathrm{Al}_{0.52}$ thin films. The films exhibited a columnar and multilayered structure due to cyclical gradient concentration deposition. The thickness of the $\mathrm{Ru}_{0.48} \mathrm{Al}_{0.52}$ thin film was $1083 \mathrm{~nm}$. Because the number of revolutions of the substrate holder was 35 , the multilayered structure of the $\mathrm{Ru}_{0.48} \mathrm{Al}_{0.52}$ thin film had a stacking period of $31 \mathrm{~nm}$. The $\mathrm{Ru}_{0.89} \mathrm{Al}_{0.11}$ and $\mathrm{Ru}_{0.63} \mathrm{Al}_{0.37}$ thin films both exhibited stacking periods of $37 \mathrm{~nm}$ (Table 1).

Table 1. Chemical compositions, thicknesses, and stacking periods of the as-deposited Ru-Al thin films.

\begin{tabular}{ccccccccc}
\hline \multirow{2}{*}{ Sample } & \multicolumn{2}{c}{ Sputter Power $(\mathbf{W})$} & \multicolumn{2}{c}{ Chemical Composition (at.\%) } & \multicolumn{2}{c}{ Thickness (nm) } & Period \\
\cline { 2 - 9 } & $\mathbf{W}_{\mathbf{R u}}$ & $\mathbf{W}_{\mathbf{A l}}$ & $\mathbf{R u}$ & $\mathbf{A l}$ & $\mathbf{O}$ & Film & Interlayer & $\mathbf{( n m )}$ \\
\hline $\mathrm{Ru}_{0.89} \mathrm{Al}_{0.11}$ & 200 & 100 & $86.69 \pm 0.39$ & $10.89 \pm 0.02$ & $2.42 \pm 0.37$ & 1305 & 50 & 37 \\
$\mathrm{Ru}_{0.63} \mathrm{Al}_{0.37}$ & 150 & 150 & $59.33 \pm 0.32$ & $34.75 \pm 0.32$ & $5.92 \pm 0.03$ & 1312 & 50 & 37 \\
$\mathrm{Ru}_{0.48} \mathrm{Al}_{0.52}$ & 100 & 200 & $47.35 \pm 0.39$ & $52.06 \pm 0.34$ & $0.59 \pm 0.14$ & 1083 & 50 & 31 \\
\hline
\end{tabular}

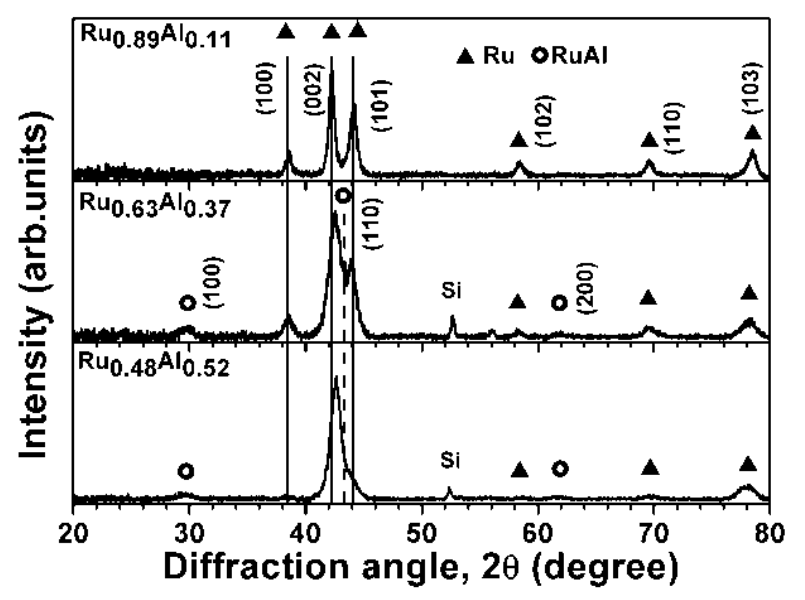

Figure 2. X-ray diffractometer (XRD) patterns of as-deposited $\mathrm{Ru}-\mathrm{Al}$ thin films. 


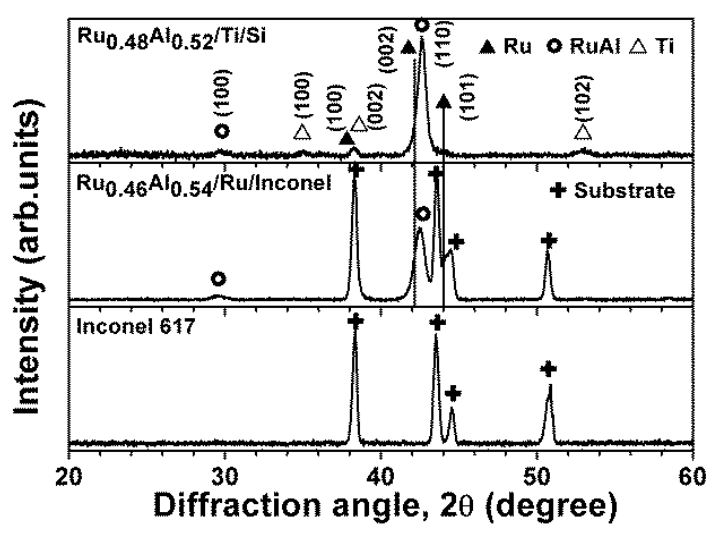

Figure 3. Bragg-Brentano scan of XRD patterns from the Inconel substrate, $\mathrm{Ru}_{0.46} \mathrm{Al}_{0.54} / \mathrm{Ru} / \mathrm{Inconel}$, and $\mathrm{Ru}_{0.48} \mathrm{Al}_{0.52} / \mathrm{Ti} / \mathrm{Si}$ samples.

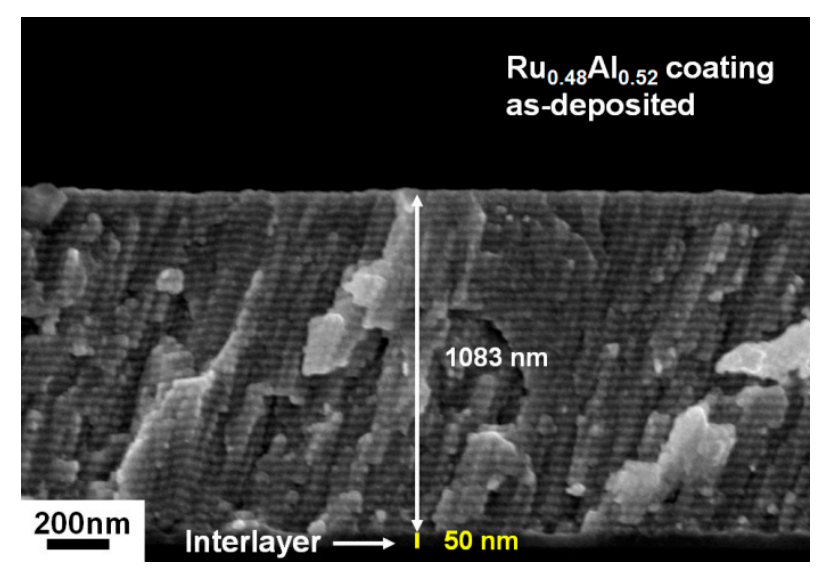

Figure 4. Cross-sectional SEM image of the as-deposited $\mathrm{Ru}_{0.48} \mathrm{Al}_{0.52}$ thin films.

\section{2. $R u_{0.48} A l_{0.52}$ Thin Films Annealed in $1 \% \mathrm{O}_{2}-99 \%$ Ar at $600{ }^{\circ} \mathrm{C}$}

Figure 5 presents a cross-sectional SEM image of the $\mathrm{Ru}_{0.48} \mathrm{Al}_{0.52}$ thin films that were annealed in $1 \% \mathrm{O}_{2}-99 \%$ Ar at $600{ }^{\circ} \mathrm{C}$ for $24 \mathrm{~h}$. The surface oxide scales were not evident and the laminated layers were maintained. The thickness of the films increased slightly from 1083 to $1102 \mathrm{~nm}$, whereas the Ti interlayer increased from 50 to $151 \mathrm{~nm}$, implying the interdiffusion of Ti and Si. Figure 6 exhibits the XRD patterns of the annealed $\mathrm{Ru}_{0.48} \mathrm{Al}_{0.52}$ thin films. $\mathrm{RuO}_{2}$ reflections [ICDD 00-040-1290] were observed after annealing for $30 \mathrm{~min}$. Ru and RuAl phases were observed even after annealing for up to $24 \mathrm{~h}$. Figure $7 \mathrm{a}$ exhibits the cross-sectional TEM image of the $24 \mathrm{~h}$-annealed $\mathrm{Ru}_{0.48} \mathrm{Al}_{0.52}$ thin films, in which the multilayered structure was maintained. The EDS results qualitatively indicated that the surface scale was Al-oxide (Position 1), and the O content exhibited a higher level of 14-25 at.\% for the first stacking periods (Positions 2 and 3). The columnar structure had a width of $50 \mathrm{~nm}$. The original $\mathrm{Ru}$ toplayer disappeared; this may be attributed to the oxidation of $\mathrm{Ru}$ to the higher valance states of $\mathrm{RuO}_{3}$ or $\mathrm{RuO}_{4}$, which are volatile $[20,27,28]$. Because the standard Gibbs free energies of $\mathrm{RuO}_{3}$ and $\mathrm{RuO}_{4}$ at $600{ }^{\circ} \mathrm{C}$ are -16.908 and $-28.003 \mathrm{~kJ} /\left(\mathrm{mol}\right.$ of $\left.\mathrm{O}_{2}\right)$ [29], respectively, and the atmosphere was constructed by constantly flowing $\mathrm{O}_{2}$-Ar mixed gases into a tube furnace, the formation of these volatile oxides was possible. In a previous study [22], partial Re atoms in IrRe films formed volatile $\mathrm{Re}_{2} \mathrm{O}_{7}$ and escaped after annealing in $1 \% \mathrm{O}_{2}-99 \%$ Ar at $600{ }^{\circ} \mathrm{C}$ for $500 \mathrm{~min}$. The EDS results also indicated that Positions 5 and 7 were Ru-enriched black sublayers, whereas Positions 4, 6, and 8 were $\mathrm{Al}$-enriched gray sublayers. The columnar boundaries may have provided oxygen diffusion paths $[21,30]$ in the early oxidation stage. High-resolution TEM imaging indicated that the surface 
Al-oxide scale was amorphous, and the lattice fringes of $\mathrm{RuO}_{2}$ were observed beneath the surface oxide layer (Figure 7b). The amorphous Al-oxide sublayer restricted oxidation at $600{ }^{\circ} \mathrm{C}$ in $1 \% \mathrm{O}_{2}-99 \% \mathrm{Ar}$. The oxidation of the $\mathrm{Ru}_{0.48} \mathrm{Al}_{0.52}$ thin films at $600{ }^{\circ} \mathrm{C}$ in $1 \% \mathrm{O}_{2}-99 \%$ Ar was similar to that of the $\mathrm{Ru}_{0.63} \mathrm{Al}_{0.37}$ thin films that were reported previously [21]. The oxidation depth of $\mathrm{Ru}_{0.63} \mathrm{Al}_{0.37}$ thin films after annealing for $24 \mathrm{~h}$ was approximately the outmost two stacking periods. By contrast, the $\mathrm{Ru}_{0.89} \mathrm{Al}_{0.11}$ thin films detached after they were annealed in $1 \% \mathrm{O}_{2}-99 \%$ Ar at $600{ }^{\circ} \mathrm{C}$ for $30 \mathrm{~min}$. Because the as-deposited $\mathrm{Ru}_{0.89} \mathrm{Al}_{0.11}, \mathrm{Ru}_{0.63} \mathrm{Al}_{0.37}$, and $\mathrm{Ru}_{0.48} \mathrm{Al}_{0.52}$ thin films exhibited similar residual stress levels of $1.57 \pm 0.16,1.43 \pm 0.16$, and $1.61 \pm 0.29 \mathrm{GPa}$, respectively, the detachment of the $\mathrm{Ru}_{0.89} \mathrm{Al}_{0.11}$ films was attributed to a high oxide-metal-volume ratio of 2.32 for $\mathrm{RuO}_{2} / \mathrm{Ru}$. This value was determined using an XRD database.

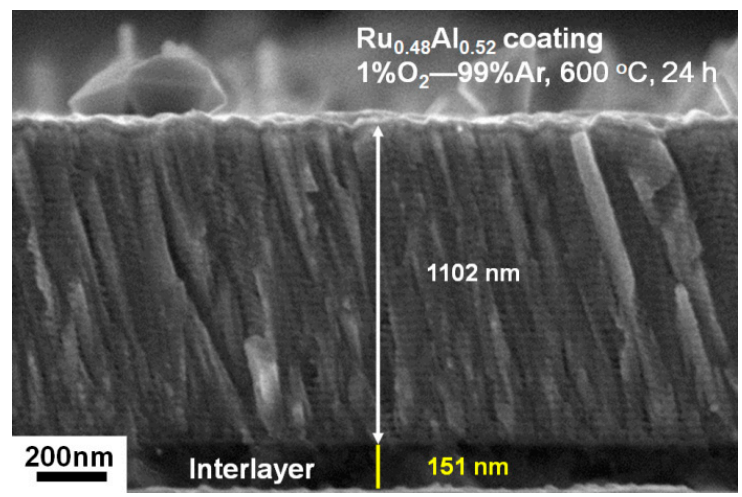

Figure 5. Cross-sectional SEM image of the $\mathrm{Ru}_{0.48} \mathrm{Al}_{0.52}$ thin films annealed in $1 \% \mathrm{O}_{2}-99 \%$ Ar at $600{ }^{\circ} \mathrm{C}$ for $24 \mathrm{~h}$.

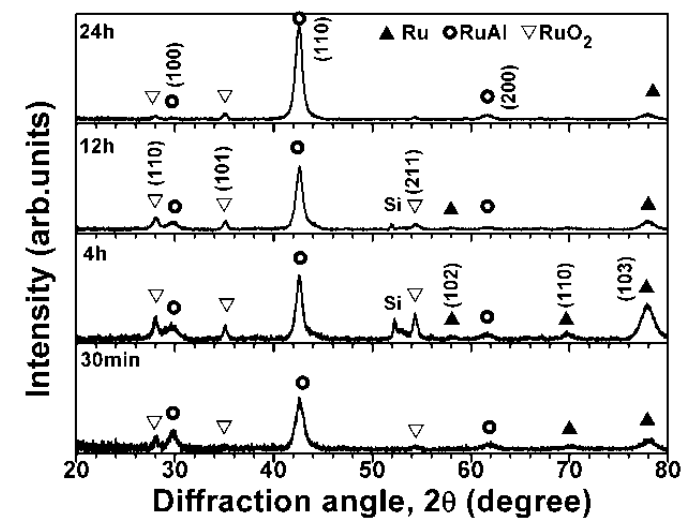

Figure 6. XRD patterns of the $\mathrm{Ru}_{0.48} \mathrm{Al}_{0.52}$ thin films annealed in $1 \% \mathrm{O}_{2}-99 \%$ Ar at $600{ }^{\circ} \mathrm{C}$ for $0.5-24 \mathrm{~h}$.
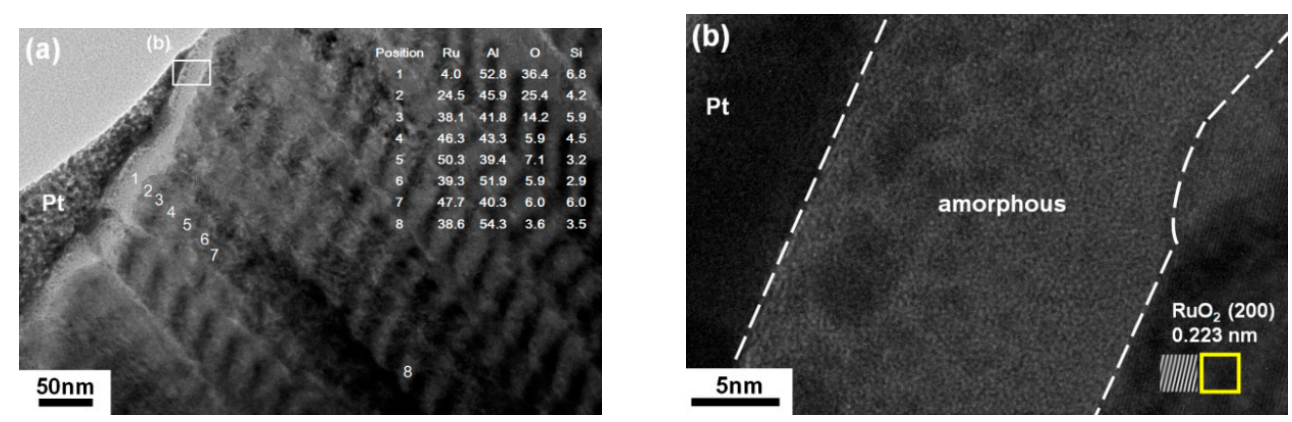

Figure 7. (a) Cross-sectional transmission electron microscopy (TEM) image and (b) high-resolution TEM image of the $\mathrm{Ru}_{0.48} \mathrm{Al}_{0.52}$ thin films annealed in $1 \% \mathrm{O}_{2}-99 \%$ Ar at $600{ }^{\circ} \mathrm{C}$ for $24 \mathrm{~h}$. 


\section{3. $\mathrm{Ru}-\mathrm{Al}$ Thin Films Annealed in Air at $800^{\circ} \mathrm{C}$}

Table 2 presents the chemical compositions of the $\mathrm{Ru}-\mathrm{Al}$ thin films deposited on Inconel 617 substrates with a $\mathrm{Ru}$ interlayer. These thin films were denoted as $\mathrm{Ru}_{0.81} \mathrm{Al}_{0.19}, \mathrm{Ru}_{0.61} \mathrm{Al}_{0.39}$, and $\mathrm{Ru}_{0.46} \mathrm{Al}_{0.54}$. Figure 8 depicts XRD patterns of the $\mathrm{Ru}-\mathrm{Al}$ thin films that were prepared on Inconel 617 substrates with a Ru interlayer. These patterns were similar to those of the $\mathrm{Ru}-\mathrm{Al}$ thin films prepared on $\mathrm{Si}$ substrates with a Ti interlayer (Figure 2). The $\mathrm{Ru}_{0.81} \mathrm{Al}_{0.19}$ thin films exhibited a Ru phase, and the $\mathrm{Ru}_{0.61} \mathrm{Al}_{0.39}$ and $\mathrm{Ru}_{0.46} \mathrm{Al}_{0.54}$ thin films exhibited a mixture of $\mathrm{RuAl}$ and $\mathrm{Ru}$ phases. Because both the Ti and $\mathrm{Ru}$ interlayers have hexagonal phases, the crystalline phases of $\mathrm{Ru}-\mathrm{Al}$ thin films deposited on the two interlayers were the same. The reflections of the Inconel 617 substrates were not observed due to low intensity and overlapping with reflections of $\mathrm{Ru}$ and RuAl phases. The XRD patterns of an Inconel 617 substrate and the $\mathrm{Ru}_{0.46} \mathrm{Al}_{0.54} / \mathrm{Ru} /$ Inconel samples under a Bragg-Brentano scan are presented in Figure 3. Figure 9 exhibits the XRD patterns of the $\mathrm{Ru}-\mathrm{Al}$ thin films after they were annealed in air at $800{ }^{\circ} \mathrm{C}$ for $30 \mathrm{~min}$. $\mathrm{Ru}$ and $\mathrm{RuO}_{2}$ dominated the crystalline phases, whereas

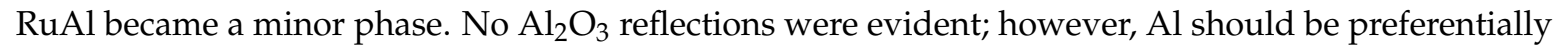
oxidized, implying that the Al-oxide should be X-ray amorphous. Part of the annealed $\mathrm{Ru}_{0.81} \mathrm{Al}_{0.19}$ thin films detached after annealing. This phenomenon was similar to that of the $1 \% \mathrm{O}_{2}-99 \% \mathrm{Ar}, 600{ }^{\circ} \mathrm{C}$, and 30 min-annealed $\mathrm{Ru}_{0.89} \mathrm{Al}_{0.11}$ thin films prepared on $\mathrm{Si}$ substrates. Figure 10 illustrates the surface morphologies of the $\mathrm{Ru}_{0.61} \mathrm{Al}_{0.39}$ and $\mathrm{Ru}_{0.46} \mathrm{Al}_{0.54}$ thin films after they were annealed in air at $800{ }^{\circ} \mathrm{C}$ for $30 \mathrm{~min}$. No spallation was evident, but cracks and small granular oxide particles were observed on the surface of the annealed $\mathrm{Ru}_{0.61} \mathrm{Al}_{0.39}$ films, whereas the annealed $\mathrm{Ru}_{0.46} \mathrm{Al}_{0.54}$ films only exhibited oxide particles.

Table 2. Chemical compositions of Ru-Al thin films deposited on Inconel 617 with a Ru interlayer.

\begin{tabular}{cccccc}
\hline \multirow{2}{*}{ Sample } & \multicolumn{2}{c}{ Sputter Power $(\mathbf{W})$} & \multicolumn{3}{c}{ Chemical Composition (at.\%) } \\
\cline { 2 - 6 } & $\mathbf{W}_{\mathbf{R u}}$ & $\mathbf{W}_{\mathbf{A l}}$ & $\mathbf{R u}$ & $\mathbf{A l}$ & $\mathbf{O}$ \\
\hline as-deposited & & & & & \\
$\mathrm{Ru}_{0.81} \mathrm{Al}_{0.19}$ & 200 & 100 & $80.02 \pm 0.58$ & $19.16 \pm 0.24$ & $0.82 \pm 0.78$ \\
$\mathrm{Ru}_{0.61} \mathrm{Al}_{0.39}$ & 150 & 150 & $57.16 \pm 0.20$ & $37.16 \pm 0.06$ & $5.68 \pm 0.15$ \\
$\mathrm{Ru}_{0.46} \mathrm{Al}_{0.54}$ & 100 & 200 & $44.80 \pm 0.03$ & $52.54 \pm 0.15$ & $2.66 \pm 0.13$ \\
\hline
\end{tabular}

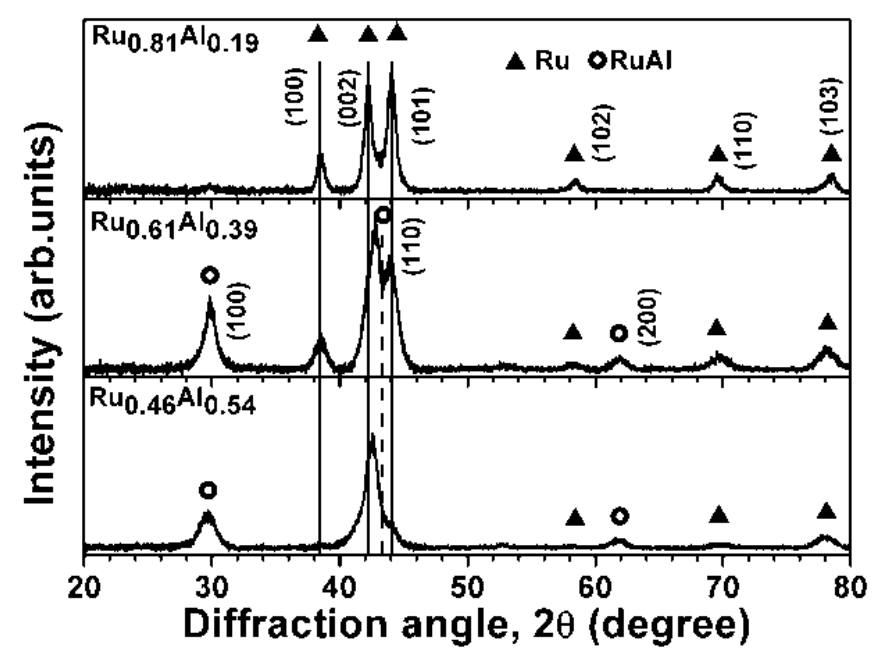

Figure 8. XRD patterns of the as-deposited $\mathrm{Ru}-\mathrm{Al}$ thin films prepared on Inconel 617 substrates with a $\mathrm{Ru}$ interlayer. 


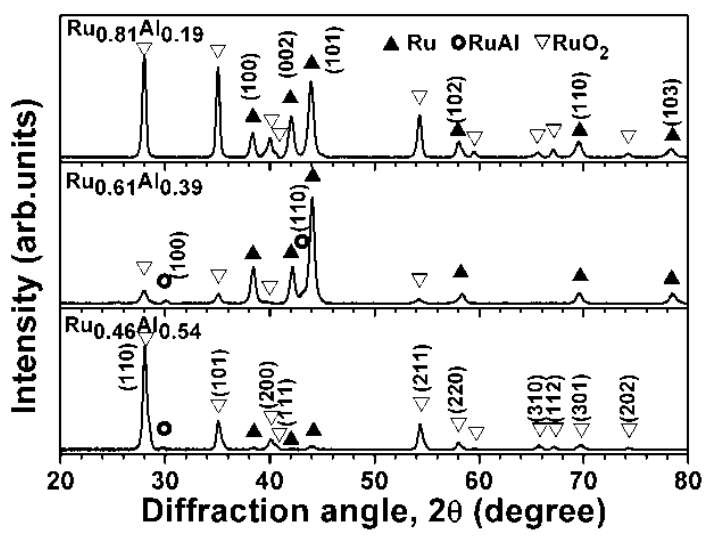

Figure 9. XRD patterns of the $\mathrm{Ru}-\mathrm{Al}$ thin films prepared on Inconel 617 substrates with a Ru interlayer and annealed in air at $800{ }^{\circ} \mathrm{C}$ for $30 \mathrm{~min}$.
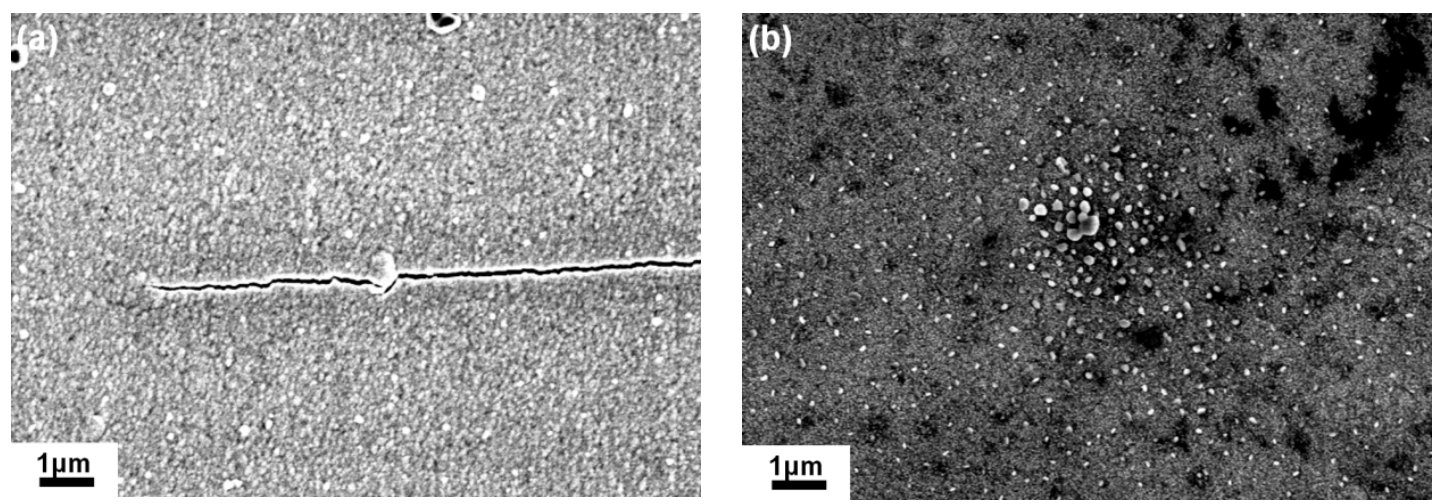

Figure 10. Surface morphologies of the (a) $\mathrm{Ru}_{0.61} \mathrm{Al}_{0.39}$ and (b) $\mathrm{Ru}_{0.46} \mathrm{Al}_{0.54}$ thin films after they were annealed in air at $800{ }^{\circ} \mathrm{C}$ for $30 \mathrm{~min}$.

Figure 11 presents the cross-sectional TEM image of the $\mathrm{Ru}_{0.61} \mathrm{Al}_{0.39}$ thin films after annealing in air at $800{ }^{\circ} \mathrm{C}$ for $30 \mathrm{~min}$. The image indicated a reaction region of $373 \mathrm{~nm}$, an unoxidized thin film of $1094 \mathrm{~nm}$, and an interlayer of $207 \mathrm{~nm}$. The reaction region was restricted to the seven outermost stacking periods of the multilayered structure, which consisted of an oxidized region (five stacking periods) and a black region (two stacking periods). The EDS results at Positions 1 and 2 indicated a $\mathrm{Ru}-\mathrm{Al}-\mathrm{O}$ region that was attributed to the inward diffusion of $\mathrm{O}$ and the formation of nonprotective oxide accompanied by ruthenium oxide evaporation and crack development [16,31]. The EDS results indicated that the oxidation front (Position 3) consisted of Al-oxide, whereas a black region beneath the oxide scale exhibited a Ru-enriched composition (Position 4), which was attributed to the outward diffusion of $\mathrm{Al}$ at high temperatures $[18,31,32]$. Therefore, the EDS analysis on Position 3 indicated high $\mathrm{Al}$ content. The unoxidized thin film comprised large grains across several stacking periods. The EDS results indicated that elements $\mathrm{Ni}, \mathrm{Cr}, \mathrm{Co}$, and Mo diffused from Inconel 617 across the $\mathrm{Ru}$ interlayer and into the $\mathrm{Ru}_{0.61} \mathrm{Al}_{0.39}$ thin films. Figure 12 presents the cross-sectional TEM image of the $\mathrm{Ru}_{0.46} \mathrm{Al}_{0.54}$ thin films after annealing in air at $800{ }^{\circ} \mathrm{C}$ for $30 \mathrm{~min}$. The image shows an oxide scale of $366 \mathrm{~nm}$ and an unoxidized thin film of $965 \mathrm{~nm}$. The oxide scale exhibited a high O level of 46-55 at.\% at Positions 1-3, whereas Position 4 beneath the oxide scale exhibited a low O level of 3 at. $\%$. A continuous Al-oxide sublayer formed at the original fifth laminated period (Position 3 ) and restricted the subsequent inward diffusion of $\mathrm{O}$. The EDS results indicated that the $\mathrm{Al} /(\mathrm{Ru}+\mathrm{Al}) \mathrm{ratios}$ at Positions 4-6 remained at $0.53-0.58$, which was closed to the corresponding values of the as-deposited $\mathrm{Ru}_{0.46} \mathrm{Al}_{0.54}$ thin films. Additionally, four periods that were close to the thin-film/interlayer interface 
surrounding Position 6 thickened, which was attributed to the outward diffusion of $\mathrm{Ni}, \mathrm{Cr}$, and $\mathrm{Co}$ from Inconel 617, as identified by EDS.

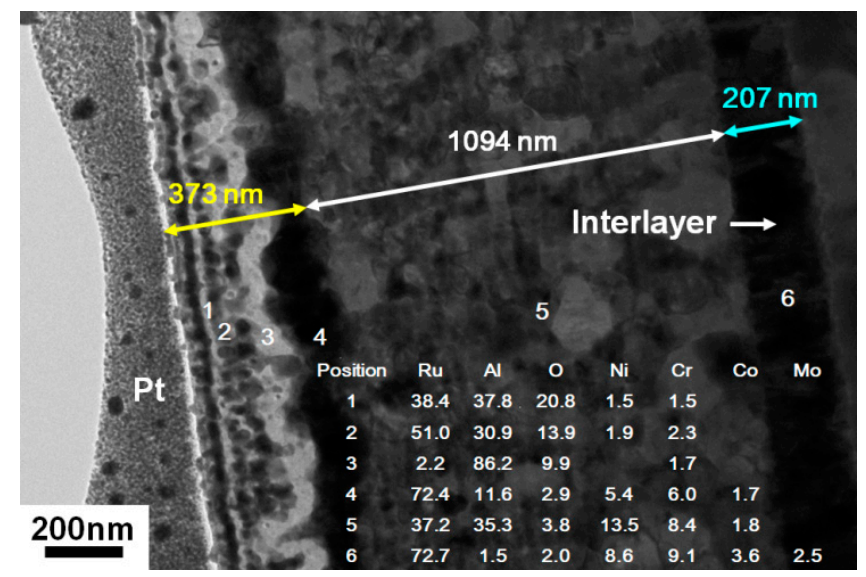

Figure 11. Cross-sectional TEM image and energy dispersive spectrometry (EDS) results for the $\mathrm{Ru}_{0.61} \mathrm{Al}_{0.39} / \mathrm{Ru} /$ Inconel 617 sample after annealing in air at $800{ }^{\circ} \mathrm{C}$ for $30 \mathrm{~min}$.

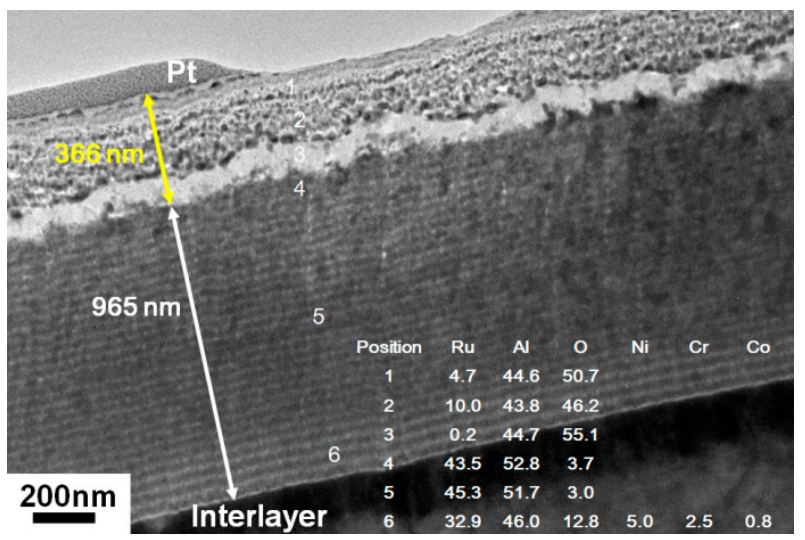

Figure 12. Cross-sectional TEM image and EDS results for the $\mathrm{Ru}_{0.46} \mathrm{Al}_{0.54} / \mathrm{Ru} /$ Inconel 617 sample after annealing in air at $800{ }^{\circ} \mathrm{C}$ for $30 \mathrm{~min}$.

Figure 13 presents the XRD patterns of the $\mathrm{Ru}_{0.46} \mathrm{Al}_{0.54} / \mathrm{Ru} /$ Inconel 617 sample after annealing in air at $800{ }^{\circ} \mathrm{C}$ for $4 \mathrm{~h}$. The patterns exhibited reflections of $\mathrm{RuAl}, \mathrm{RuO}_{2}, \gamma-\mathrm{Al}_{2} \mathrm{O}_{3}$ [ICDD 00-050-0741], and $\alpha-\mathrm{Al}_{2} \mathrm{O}_{3}$ [ICDD 00-046-1212] phases. Figure 14a depicts the cross-sectional TEM image of the $\mathrm{Ru}_{0.46} \mathrm{Al}_{0.54}$ thin films after annealing in air at $800{ }^{\circ} \mathrm{C}$ for $4 \mathrm{~h}$; this image exhibited an oxide scale of $140 \mathrm{~nm}$ and an inner part of $1345 \mathrm{~nm}$. The inner part comprised an interdiffused film, interlayer, and substrate. The oxide scale exhibited a high $\mathrm{O}$ level of 45 at.\% at Position 1, for which a high-resolution TEM image exhibited lattice fringes of crystalline $\alpha-\mathrm{Al}_{2} \mathrm{O}_{3}$ (Figure $14 \mathrm{~b}$ ). The depth of the oxide scale of the $4 \mathrm{~h}$-annealed $\mathrm{Ru}_{0.46} \mathrm{Al}_{0.54}$ thin films appeared to be less than that of the 30 min-annealed films (Figure 12), which implied that the outmost oxidized part of the films volatilized during further oxidation, and only the $\mathrm{Al}_{2} \mathrm{O}_{3}$-dominant oxide scale remained. Figure $14 \mathrm{c}$ represents the $\mathrm{RuAl}$ grains of $200 \mathrm{~nm}$ that were beneath the oxide scale. 


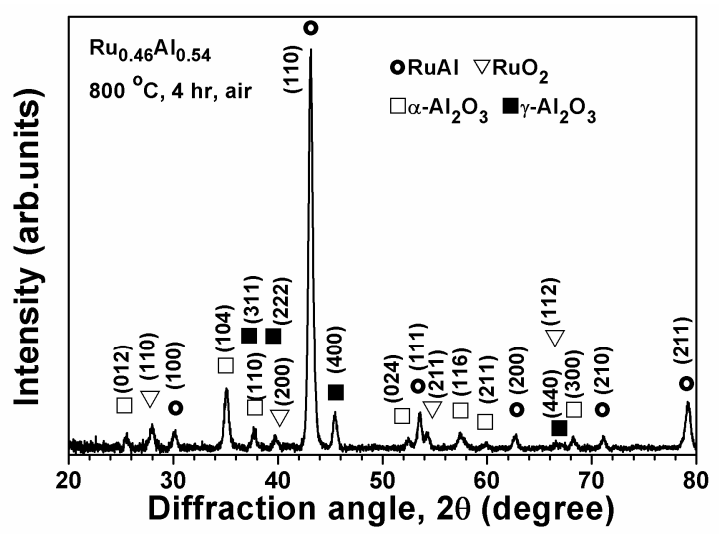

Figure 13. XRD pattern of the $\mathrm{Ru}_{0.46} \mathrm{Al}_{0.54} / \mathrm{Ru} /$ Inconel 617 sample after annealing in air at $800{ }^{\circ} \mathrm{C}$ for $4 \mathrm{~h}$.
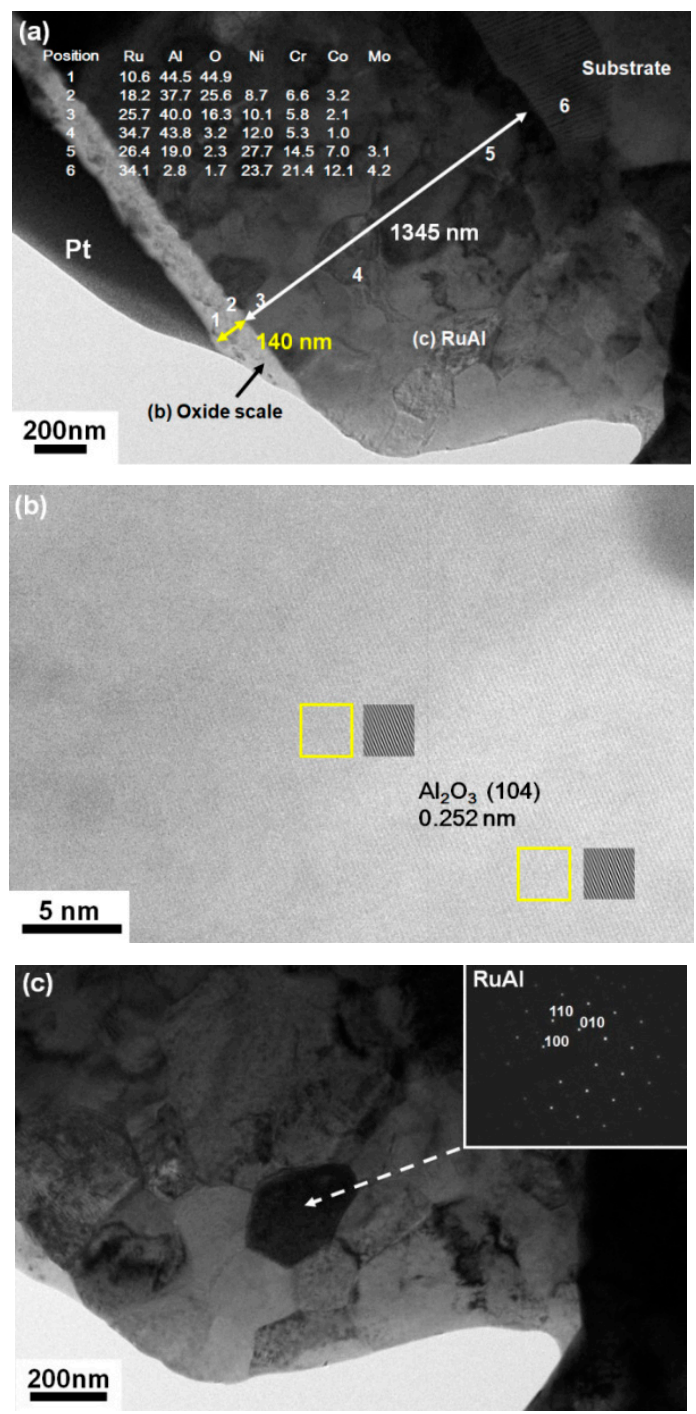

Figure 14. (a) Cross-sectional TEM image of the $\mathrm{Ru}_{0.46} \mathrm{Al}_{0.54}$ thin films annealed in air at $800{ }^{\circ} \mathrm{C}$ for $4 \mathrm{~h}$, (b) high-resolution TEM image of the surface oxide scale, and (c) a RuAl grain beneath the oxide scale. 


\section{Conclusions}

$\mathrm{Ru}-\mathrm{Al}$ multilayered thin films that were stacked with cyclical gradient concentration were fabricated through cosputtering. The oxidation depth of $\mathrm{Ru}_{0.48} \mathrm{Al}_{0.52}$ thin films that were annealed in a $1 \% \mathrm{O}_{2}-99 \% \mathrm{Ar}$ atmosphere at $600{ }^{\circ} \mathrm{C}$ for $24 \mathrm{~h}$ was restricted at the outmost two stacking periods, which behaved similar to that of the $\mathrm{Ru}_{0.63} \mathrm{Al}_{0.37}$ thin films and was attributed to the formation of amorphous Al-oxide sublayers restricting the inward diffusion of O. Additionally, the oxidation fronts to five stacking periods of the $\mathrm{Ru}_{0.46} \mathrm{Al}_{0.54}$ and $\mathrm{Ru}_{0.61} \mathrm{Al}_{0.39}$ thin films after they were annealed in air at $800{ }^{\circ} \mathrm{C}$ for $30 \mathrm{~min}$. The Al-oxide sublayers remained amorphous. In the interior part of the $\mathrm{Ru}_{0.61} \mathrm{Al}_{0.39}$ films, (i.e., the unoxidized portions) the multilayered structure transformed into large grains, accompanied by outward diffusion of Inconel 617 substrate elements. By contrast, the unoxidized part of the $\mathrm{Ru}_{0.46} \mathrm{Al}_{0.54}$ films maintained its multilayer structure after $30 \mathrm{~min}$ of annealing, and the diffusion of elements from the substrate was limited. An extending annealing time of $4 \mathrm{~h}$ resulted in the formation of a crystalline $\alpha-\mathrm{Al}_{2} \mathrm{O}_{3}$-dominated oxide scale on the surface of the $\mathrm{Ru}_{0.46} \mathrm{Al}_{0.54}$ films, and the original $\mathrm{Ru}$ on the surface region formed volatile oxides. Additionally, beneath the $\alpha-\mathrm{Al}_{2} \mathrm{O}_{3}$ oxide scale, the structure transformed into large grains of $\mathrm{RuAl}$ phase accompanied by the outward diffusion of substrate elements. Modification of the Ru-Al multilayered thin films by introducing a third element to form a diffusion barrier for constitutive elements of Inconel 617 is a major concern that should be addressed in future research.

Author Contributions: Conceptualization, Project Administration, and Writing-Original Draft Preparation, Y.-I.C.; Investigation, Z.-T.Z. and J.-W.J.

Funding: This research was funded by the Ministry of Science and Technology, Taiwan. The grant number is 106-2221-E-019-022-MY3.

Acknowledgments: The support of Inconel 617 materials from Wu Kai at National Taiwan Ocean University is greatly acknowledged.

Conflicts of Interest: The authors declare no conflict of interest.

\section{References}

1. Rahman, M.d.S.; Priyadarshan, G.; Raja, K.S.; Nesbitt, C.; Misra, M. Characterization of high temperature deformation behavior of INCONEL 617. Mech. Mater. 2009, 41, 261-270. [CrossRef]

2. Gariboldi, E.; Cabibbo, M.; Spigarelli, S.; Ripamonti, D. Investigation on precipitation phenomena of $\mathrm{Ni}-22 \mathrm{Cr}-12 \mathrm{Co}-9 \mathrm{Mo}$ alloy aged and crept at high temperature. Int. J. Press. Vessel. Pip. 2008, 85, 63-71. [CrossRef]

3. DeMasi-Marcin, J.T.; Gupta, D.K. Protective coatings in the gas turbine engine. Surf. Coat. Technol. 1994, 68-69, 1-9. [CrossRef]

4. Vaßen, R.; Jarligo, M.O.; Steinke, T.; Mack, D.E.; Stöver, D. Overview on advanced thermal barrier coatings. Surf. Coat. Technol. 2010, 205, 938-942. [CrossRef]

5. Miller, R.A. Current status of thermal barrier coatings-An overview. Surf. Coat. Technol. 1987, 30, 1-11. [CrossRef]

6. Evans, A.G.; Mumm, D.R.; Hutchinson, J.W.; Meier, G.H.; Pettit, F.S. Mechanisms controlling the durability of thermal barrier coatings. Prog. Mater. Sci. 2001, 46, 505-553. [CrossRef]

7. Aygun, A.; Vasiliev, A.L.; Padture, N.P.; Ma, X. Novel thermal barrier coatings that are resistant to high-temperature attack by glassy deposits. Acta Mater. 2007, 55, 6734-6745. [CrossRef]

8. Huang, J.; Wang, W.; Lu, X.; Hu, D.; Feng, Z.; Guo, T. Effect of particle size on the thermal shock resistance of plasma-sprayed YSZ coatings. Coatings 2017, 7, 150. [CrossRef]

9. Hu, N.; Khan, M.; Wang, Y.; Song, X.; Lin, C.; Chang, C.; Zeng, Y. Effect of Microstructure on the Thermal Conductivity of Plasma Sprayed $\mathrm{Y}_{2} \mathrm{O}_{3}$ Stabilized Zirconia (8\% YSZ). Coatings 2017, 7, 198. [CrossRef]

10. Mücklich, F.; Ilić, N. RuAl and its alloys. Part I. Structure physical properties, microstructure and processing. Intermetallics 2005, 13, 5-21. [CrossRef]

11. Mücklich, F.; Ilić, N.; Wol, K. RuAl and its alloys, part II: Mechanical properties, environmental resistance and applications. Intermetallics 2008, 16, 593-608. [CrossRef] 
12. Tryon, B.; Pollock, T.M.; Gigliotti, M.F.X.; Hemker, K. Thermal expansion behavior of ruthenium aluminides. Scr. Mater. 2014, 50, 845-848. [CrossRef]

13. Tryon, B.; Feng, Q.; Wellman, R.G.; Murphy, K.S.; Yang, J.; Levi, C.G.; Nicholls, J.R.; Pollock, T.M. Multilayered ruthenium-modified bond coats for thermal barrier coatings. Metall. Mater. Trans. A 2006, 37A, 3347-3358. [CrossRef]

14. Wang, Y.; Guo, H.B.; Peng, H.; Peng, L.Q.; Gong, S.K. Diffusion barrier behaviors of (Ru,Ni)Al/NiAl coatings on Ni-based superalloy substrate. Intermetallics 2011, 19, 191-195. [CrossRef]

15. Guitar, M.A.; Woll, K.; Ramos-Moore, E.; Mücklich, F. Study of grain growth and thermal stability of nanocrystalline RuAl thin films deposited by magnetron sputtering. Thin Solid Films 2013, 527, 1-8. [CrossRef]

16. Guitar, M.A.; Ramos-Moore, E.; Mücklich, F. The influence of impurities on the formation of protective aluminum oxides on RuAl thin films. J. Alloys Compd. 2014, 594, 165-170. [CrossRef]

17. Seifert, M.; Menzel, S.B.; Rane, G.K.; Hoffmann, M.; Gemming, T. RuAl thin films on high-temperature piezoelectric substrates. Mater. Res. Express 2015, 2, 085001. [CrossRef]

18. Seifert, M.; Rane, G.K.; Menzel, S.B.; Gemming, T. TEM studies on the changes of the composition in LGS and CTGS substrates covered with a RuAl metallization and on the phase formation within the RuAl film after heat treatment at 600 and $800{ }^{\circ} \mathrm{C}$. J. Alloys Compd. 2016, 664, 510-517. [CrossRef]

19. Seifert, M.; Rane, G.K.; Menzel, S.B.; Gemming, T. The influence of barrier layers $\left(\mathrm{SiO}_{2}, \mathrm{Al}_{2} \mathrm{O}_{3}, \mathrm{~W}\right)$ on the phase formation and stability of RuAl thin films on LGS and CTGS substrates for surface acoustic wave technology. J. Alloys Compd. 2016, 688, 228-240. [CrossRef]

20. Seifert, M.; Rane, G.K.; Oswald, S.; Menzel, S.B.; Gemming, T. The influence of the composition of $\mathrm{Ru}_{100-x} \mathrm{Al}_{x}$ $(x=50,55,60,67)$ thin films on their thermal stability. Materials 2017, 10, 277. [CrossRef] [PubMed]

21. Chen, Y.I.; Zheng, Z.T.; Kai, W.; Huang, Y.R. Oxidation behavior of Ru-Al multilayer coatings. Appl. Surf. Sci. 2017, 406, 1-7. [CrossRef]

22. Liu, S.C.; Chen, Y.I.; Tsai, H.Y.; Lin, K.C.; Chen, Y.H. Thermal stability of Ir-Re coatings annealed in oxygen-containing atmospheres. Surf. Coat. Technol. 2013, 237, 105-111. [CrossRef]

23. Chen, Y.I. Laminated structure in internally oxidized Ru-Ta coatings. Thin Solid Films 2012, 524, $205-210$. [CrossRef]

24. Chen, Y.I.; Lu, T.S.; Zheng, Z.T. Internally oxidized Ru-Zr multilayer coatings. Coatings 2017, 7, 46. [CrossRef]

25. Janssen, G.C.A.M.; Abdalla, M.M.; van Keulen, F.; Pujada, B.R.; van Venrooy, B. Celebrating the 100th anniversary of the Stoney equation for film stress: Developments from polycrystalline steel strips to single crystal silicon wafers. Thin Solid Films 2009, 517, 1858-1867. [CrossRef]

26. Deng, Y.L.; Lee, J.W.; Lou, B.S.; Duh, J.G.; Chu, J.P.; Jang, J.S.C. The fabrication and property evaluation of Zr-Ti-B-Si thin film metallic glass materials. Surf. Coat. Technol. 2014, 259, 115-122. [CrossRef]

27. Bell, W.E.; Tagami, M. High-temperature chemistry of the ruthenium-oxygen system. J. Phys. Chem. 1963, 67, 2432-2436. [CrossRef]

28. Huang, J.H.; Chen, J.S. Material characteristics and electrical property of reactively sputtered RuO thin films. Thin Solid Films 2001, 382, 139-145. [CrossRef]

29. Barin, I. Thermochemical Data of Pure Substances, 3rd ed.; VCH: New York, NY, USA, 1995.

30. Chen, Y.I.; Chu, H.N.; Kai, W. Internal oxidation of laminated Nb-Ru coatings. Appl. Surf. Sci. 2016, 389, 477-483. [CrossRef]

31. Bellina, P.J.; Catanoiu, A.; Morales, F.M.; Rühle, M. Formation of discontinuous $\mathrm{Al}_{2} \mathrm{O}_{3}$ layers during high-temperature oxidation of RuAl alloys. J. Mater. Res. 2006, 21, 276-286. [CrossRef]

32. Soldera, F.; Ilić, N.; Brännström, S.; Barrientos, I.; Gobran, H.; Mücklich, F. Formation of $\mathrm{Al}_{2} \mathrm{O}_{3}$ scales on single-phase RuAl produced by reactive sintering. Oxid. Met. 2003, 59, 529-542. [CrossRef]

(C) 2018 by the authors. Licensee MDPI, Basel, Switzerland. This article is an open access article distributed under the terms and conditions of the Creative Commons Attribution (CC BY) license (http://creativecommons.org/licenses/by/4.0/). 